\title{
With and Without 'General': The Representation of Wiranto in The Sydney Morning Herald during Indonesia's 2004 General Election
}

\author{
Aylanda Hidayati Dwi-Nugroho \\ English Department, Faculty of Letters, Petra Christian University, Surabaya, INDONESIA \\ e-mail: aylanda@peter.petra.ac.id
}

\begin{abstract}
This paper reports an analysis on the naming and title-giving practices of The Sydney Morning Herald toward General Wiranto in the news about Indonesia's 2004 General Election when he contested as a presidential candidate but failed. In the news data he was mostly related to the allegations of his responsibility as the Commander of Indonesia's armed forces for a number of atrocities committed by the Indonesian military and Jakarta-backed militias in East Timor. Honorification is one standard referencing in news. Its presence is believed to indicate respects, and its absence can be interpreted as either showing solidarity or less respect. However, Wiranto was negatively represented both when he was referred to with and without his military title. Such a representation suggests the newspaper's perception and stereotype it has had about Wiranto.
\end{abstract}

Keywords: Wiranto, media representation, news actor, honorification, Australian-Indonesia relations.

\section{INTRODUCTION}

What we read in the news should not be understood as what actually happened. Rather, it should be seen as the news writer's perception and representation of what has happened. Events have been transformed by the writers through recontextualizing processes (Fairclough, 2003; van Leeuwen, 2008) to fit news discourse. They have selected which and how events and actors are reported. Events presented in the news have also been framed (D'Angelo \& Kuypers, 2010) in such a way to achieve the writers' goals of writing. This concept, however, should not be either understood that the writers report fictitious actors and happenings, because news writers are constrained by institutional and societal conventions to report factual news events (Berkowitz, 1997). Thus, news should rather be seen as the representation of real people and actual events which have been perceived by the news writers (e.g., O'Shaughnesssy \& Stadler, 2005).

Representations in the news have been debated by scholars in media analysis and those involved in media production. Media people believe that they have maintained balance and objectivity, avoided bias, and promoted independence in reporting news events. However, research in media analysis have shown imbalanced coverage of news actors (e.g.,
Stevens-Gupta, 2011), misrepresentation of a minority group (e.g., Koshravinik, 2009), and stereotyping of certain groups of people (e.g., Darke, 2005). This paper attempts to bridge these poles by observing how news representations are produced and consumed through the social and cognitive perspectives (Dwi-Nugroho, 2013).

The social perspective sees news as circulating within the social realm, because news is produced by some members of the society and consumed by the general society. News is very influential in shaping the society and it is also shaped by the society (Fairclough, 1997). Representations in the news use social and cultural codes which are commonly used and understood by the society. The cognitive perspective maintains that news production and consumption are cognitive activities. In the news production process, news writers are by all means influenced by their knowledge, past experiences, norms and values, ideologies, and purposes of writing. This is evident in the way one same news event is framed and reported with a different slant by different news writers, editors and newspapers. In the comprehension process, readers with similar knowledge, experiences, values, and social cultural codes to those of the writers will understand news texts more easily than readers lacking these. 
This paper analyzes the representation of former General Wiranto in an Australian broadsheet, The Sydney Morning Herald. In 1998, he was both the Minister of Defense and Security and the Commander of Indonesia's armed forces under Soeharto's government. He was strongly criticized in Australian media because he was seen responsible for the alleged atrocities of the Indonesian military and militias in East Timor (In 2002 it became an independent state Timor Leste). It was basically argued that the kidnapping, torturing, house-burning, raping and other brutal acts taking place in many regions in East Timor would not have been possible without the consent of the high-ranking officers. Otherwise, the lower-rank officers involved in the brutality would have been directly prosecuted. However, Wiranto, as many other higher-ranking officers, has denied any responsibility and was never sent to any tribunal to prove his otherwise innocence. Instead, he could even become one of the leading candidates in the 2004 presidential election. The negative-leaning representation of him in the Australian news could appear repeatedly because there has never been a closure for the allegations.

Australia has supported East Timor in her struggle to achieve freedom since the Indonesian 'invasion' in 1975. While its government was trying to court a good relationship with Soeharto's government, its news media have been very critical of him (Kingsbury, 1997). The Sydney Morning Herald (SMH) as one of the mainstream broadsheets published by Fairfax Media in Australia has one correspondent stationed in Jakarta. Consequently, the news on Indonesia are of eyewitness report types for the consumption of Australian readers. This can create a sense of familiarity among the readers about what is going on in Indonesia. However, the readers' social cognition about Indonesia may also be strongly influenced by the newspaper's perception about Indonesia.

Following Fairclough's (1989/2001, 1997) threedimensional analysis of discourse, this study also analyzes the discursive and social practices surrounding the news text data. It can be seen that the participants involved in the news representation process are people across the countries' border. The first person, or the message sender (following Jakobson's (1960) communication model), is presumably the newspaper. The second person, or the message receiver, is assumed to be Australian readers who follow news about Indonesia or Australia-Indonesia relations. Non-Australian readers may also read this topic, especially in the online edition. The third person, or the message object, is an Indonesian news actor, former General Wiranto. The subject relations and social contexts of the three determine the representations produced by the first person and how these are comprehended by the second person about the third person. For a start, both the first and second persons share more or less the same cultural codes, because they grow up and live in the same social, cultural context, Australia. Consequently, they may acquire similar values through the Australian education system. They may also experience the same historical events and how these have been socially and culturally framed and comprehended in the media. The social cognition about East Timor in the span of almost three decades must have built a negative perception about Wiranto. This could lead to building a stereotype which is recycled if current events do not strongly suggest otherwise.

The data of this study were analyzed following the principles in critical discourse analysis (CDA). This approach helps discourse analysts recognize inequality in the representions of different news actors in the news texts, and these suggest the different perceptions of the news writers about different actors. In particular, this study follows van Leeuwen's social actor framework (2008) which offers a network of choices usually used in depicting social actors. Among the recontextualizing choices in his system, this study focuses on one system only, the honorification. This system is the elaboration of nomination and titulation (van Leeuwen, 2008, p. 41), which categorize how news actors are properly named and given titles. These are further elaborations of Inclusion, Personalization, Determination and Identification. The system of recontextualization choices leading to honorification can be shown as the following.

\section{Inclusion $\rightarrow$ Personalization $\rightarrow$ Determination $\rightarrow$}

\section{Nomination $\rightarrow$ Titulation $\rightarrow$ Honorification}

First, in Inclusion, analysts must see that references about the news actors are present in the text. The news actors can further be personalized and determinized, that is, they are represented in the news in terms of their personal attributes, such as their affiliation, occupation, age, relation or special physical characteristics. They can be further nominated through their proper names, which clearly differentiate one person from the others. Names can be further titulated, for example, by giving honorification or titles in front of the names such as the standard titles (Mr, Mrs, Ms), academic titles (Dr, Prof), or militaryrank titles (General, Captain, Admiral). 
Each newspaper company has their own standard of referencing as stated in their 'house rules' (Lamble, 2011) or 'house style'. Newspapers written in English generally follow the English conventions of references or addresses. The formal naming uses "Title + Surname" (van Leeuwen, 2008, p. 41). For example, "Mr Yudhoyono" refers to President Susilo Bambang Yudhoyono, and "Mrs Yudhoyono" refers to his wife. Ladies may also be formally given the title of "Ms" before their name. The semiformal naming may use "Title + Given Name + Surname", such as Ms Julia Gillard, the Prime Minister of Australia. The third variation, the informal naming, is indicated by the use of "First/Given Name" or the "Nickname". This seldom appeared in the news, and if it is ever used, an explanation is always given. For example, the use of "SBY" to refer to President Susilo Bambang Yudhoyono in the Australian newspaper was always followed by a phrase like "as the President popularly known" (Dwi-Nugroho, 2013). It was perhaps used to avoid sounding rude. Understandably, from naming and title-giving it is not yet clear whether the representation is positive or negative.

The honorification of a news actor can further indicate certain leaning, but it is not always consistent. DwiNugroho (2013) reported that honorification may suggest not only respect or no respect, but also solidarity. First, the academic or military title may be preferred to the standard title. For example, President Susilo Bambang Yudhoyono is usually nominated as "Dr Yudhoyono" in the Australian press. The common "Mr Yudhoyono" was only used before he obtained the degree from IPB (Institut Pertanian Bogor - Bogor Agricultural University) in 2004. The honorification suggested that the news writers showed recognition of his academic achievement. Second, if the inclusion of title suggests showing respect, the exclusion of title may be thought to suggest showing no respect. In some cases, this seemed true. As examples, some Indonesian controversial figures, such as Abu Bakar Bashir, Amrozi, Ali Imron, Muklas, and Imam Samudra, who were involved in Bali bombings, were never given honorification tokens even the standard "Mr" (Dwi-Nugroho, 2013). However, this tendency cannot be generalized, because some favourable actors were not given any personal title either, such as human rights activist Munir Thalib, who was poisoned in his flight from Singapore to the Netherlands (e.g., Moore, 2004c). $\mathrm{He}$ was sometimes formally nominated as "Mr Thalib", but often informally as just "Munir". This preference suggests solidarity rather than no-respect, because the newspaper hailed his efforts to solve cases of human rights violation. His death was deeply regretted, and the indifference of the Indonesian government to sincerely investigate this matter was strongly criticized (Dwi-Nugroho, 2013). Thus, the presence or absence of title suggests only a little about the representation of news actors, and analysis should relate it to other representational choices used by the news writers in describing the news actors.

The data were taken from two news texts published in The Sydney Morning Herald (SMH) during Indonesia's 2004 general election. The first is about the meeting between Wiranto and Timor Leste's President, Mr Xanana Gusmao (Moore, 2004b), and the second article is about Wiranto's campaign in Surabaya (Moore, 2004a). The honorification, or the title-giving, of 'General Wiranto' in the news texts may suggest showing respect, while the nomination of just 'Wiranto' may suggest no-respect or solidarity in other texts. Or, these addresses are only the standard way and its variation of referring to a news actor as the house rules dictate. However, a critical analysis on the representations of him in the texts suggested a different result.

\section{DISCUSSION}

\section{Without 'General'}

The first article reported the arranged meeting between Timor Leste's President, Mr Xanana Gusmao, and Wiranto in Bali in 2004. The headline said "Forgiving Gusmao hugs Wiranto", published on May 31, 2004. In this article, Wiranto was all referred to in his single name without the military title nor even the standard title "Mr". If President Yudhoyono had been referred to as "Mr Yudhoyono", Wiranto was never addressed as "Mr Wiranto" despite the fact that both gentlemen were retired army generals.

President Gusmao, on the contrary, was mentioned five times in two ways. Once, in the opening sentence, he was introduced and functionalized as "President Xanana Gusmao" (Extract 1). This radiates the newspaper's recognition of his highest political position. It may activate the readers' collective memory which has been built from regular reading of the news about his struggle to free his country from Indonesia. The memory was now updated that he was currently the President of Timor Leste. Later in the text, President Gusmao was formally represented four times as "Mr Gusmao" (e.g., Extract 1).

(1) President Xanana Gusmao has publicly embraced the man accused of responsibility in the deaths of 1500 of his countrymen in a dramatic sign of his determination for East Timor to bury the past. 
Mr Gusmao and Wiranto, the former Indonesian armed forces commander who is standing for the presidency, met for two hours on Saturday night in Bali, ...

This unequal reference only suggested that President Gusmao was more positively represented than Wiranto. The former was formally nominated with "Mr" and his surname, and functionalized in his top official title as "President". The latter was a retired army general and once the Minister of Defence and the Commander of Indonesia's armed forces. With his highest position in the Indonesian military and his position as a cabinet member in 1998 , he could have taken over the control of the country during its chaotic demonstrations demanding Soeharto to resign. Soeharto himself gave him the Presidential Instruction to take over the country (socio-politica.com). However, Wiranto chose not to involve the military in the last days of Soeharto so that the transition proceeded smoothly and bloody clashes were prevented. However, in this article it seemed that he was stripped from his military achievements, powers, and entitlements. By just referring to him in his single name, he was just represented as a civilian.

Besides the naming and title-giving, other actions are used to support this imbalanced representation. The headline depicted President Gusmao as "forgiving", a favourable value suggesting dignity. The felicity condition of "forgiving" requires that the person receiving forgiveness has done terrible things to the person giving forgiveness, yet the latter gives pardon to the former. General Wiranto was symbolically the President's enemy, because the Indonesian military under his command had allegedly killed thousands of East Timorese, burnt their villages, raped their women and committed many other atrocities (Greenlees \& Garran, 2003). However, in the text President Gusmao was nobly represented as he forgave Wiranto and did not want to take revenge. In addition, President Gusmao was also favourably represented in his action as he "hugged" his 'former enemy'. It was never clear whether he had really forgiven Wiranto, but it was how he was represented in the news. It was not either explicitly written how the hug was, but implicitly it can be inferred from Extract 2 that it might not be a truly friendly and forgiving hug.

(2) ... where they hugged, shook hands and smiled for the cameras in gestures apparently intended to distance Mr Gusmao from a recent East Timor court warrant for Wiranto's arrest.

Extract 2 shows that the hug, handshake and smile were only "for the cameras". This suggested that those symbols of friendship were only a performance in front of the cameras, and not necessarily indicating that they were truly friends.

Further in the text, Wiranto was quoted as saying how positive and friendly his meeting with Mr Gusmao had been (Extract 3).

(3) "Much of what we spoke of was nostalgic." Wiranto said after their meeting.

"Before, we were the same in the forest, the mountains, in positions opposing each other. To see us now, it's quite funny.

"I think now we have become friends. We are two people who understand that war and battles are not good."

According to Merriam-Webster dictionary, "nostalgia" means "a wistful or excessively sentimental yearning for return to [my italics] or of some past period or irrecoverable condition". Nostalgia refers to happy memories which people cherish and wish to experience again. Nostalgia does not just mean old memories. Old friends who are separated for sometime will likely recall their happy moments together when they meet again. In the social political contexts surrounding Wiranto and Mr Gusmao, however, it is doubtful that they would develop such a nostalgia. In the second part of Extract 3, Wiranto was also quoted thinking that he and Mr Gusmao had become friends. Wiranto could say what he said, and he might have assumed that the feelings were mutual. However, without a confirmation from the other participant, Mr Gusmao, his statement may only mean a wishful thinking. Mr Gusmao was reported that up to the end of the meeting he did not make any comment (Extract 4).

(4) Mr Gusmao left the meeting without making any comment.

In a news conference, political leaders or business people may give a statement or a joint statement. It was not explained in the text why Mr Gusmao left the meeting without giving any statement. It could be difficult for him to confirm what Wiranto had said, because this could be interpreted as betraying his own people. Or, as the newspaper suggested, the 'friendly' meeting was staged, because it was just held to 'repair the damage to Wiranto's presidential campaign'. Aware of the controversy surrounding his presidential candidacy, Wiranto tried to polish his image by showing that he and President Gusmao were only patriots for their respective countries which happened to be opposing each other (Extract 3). The idea of two supposedly enemies who were now good friends was used to construct the image that the accusations towards his alledged responsibility in the brutal acts in East Timor should be wiped out. The newspaper, 
however, reported that perhaps Mr Gusmao had his own reason to willingly participate in the act. The last sentence of the news text reported that he wanted "to have good relations with Jakarta". As a young country which was economically struggling, East Timor's move to invite foreign investors from and collaborations with her neighboring country was necessary.

As a whole, in this text Wiranto had been clearly negatively represented. First is the absence of his military title and even the standard title of address. Second, his meeting with Timor Leste's President was described as politically staged and arranged only to polish his image in the presidential race. And third, without Mr Gusmao's statement Wiranto's claim of friendship could be interpreted as speaking hollow.

\section{With 'General'}

In the second article Wiranto was represented in his full military title as "General Wiranto" six times in the news about his campaign in Surabaya (Moore, 2004a). It was initially expected that he would receive a more favourable representation here than in the previous text. However, critical reading through the text shows that the title-giving was used to challenge the image of a military general and the "strong leader" theme that Wiranto proposed.

First, he was described more as a celebrity than a military general. The headline says "Let me entertain you: Wiranto woos the voters". Generals do not normally entertain people, but this general did. The verb "to woo" means to attract one's favor, affection or love for a romantic relationship (dictionary.com). Wooing may happen during initial encounters and the attraction is mostly on something superficial, for example, favourable facial and physical characteristics, and other feel-good items. This can be seen from the description of him further down in the text. It was focused more on his physical characteristics and his singing talent rather than, for example, his military roles and achievements. Extract 5 shows descriptions of him in terms of his age ("the 56-year-old"), his physique ("his dark good looks"), and his singing talent ("his even better voice"). In Extract 6, his achievements were related to entertainment and shown as something unusual, "the general with his own CD".

(5) But at home the 56-year-old is known more for his dark good looks and his even better voice, ...

(6) ... the general with his own CD.

..., but his rendition of a Javanese pop song was what the crowd was waiting for. General Wiranto's songs entertain, ...
If his military 'achievement' was ever mentioned, it was again about his alleged involvement in East Timor, as shown in Extract 7.

(7) General Wiranto is best known as the military commander whose troops orchestrated the slaughter of hundreds of East Timorese in the days surrounding their 1999 vote for independence, a version of history he still hotly contests.

The statement was emphasized with the phrase "best known". However, the following details were not anything to be proud of, because it was about "orchestrating the slaughter of hundreds of East Timorese".

Second, his idea of a "strong leader" was seriously challenged in this news. The circulating discourse at that time was that Indonesia needed a strong leader who could bring prosperity and justice back to Indonesia. Golkar often reminded the voters of the 'easy life' that Indonesians had experienced during Soeharto or Golkar-dominated government: when jobs had been easy to get, food and housing affordable, and education and healthcare not expensive. In 1999 general election, Golkar was defeated by PDIP (Partai Demokrasi Indonesia Perjuangan Indonesian Democratic Party - Struggle), a party with a huge mass support which Soeharto had tried to disintegrate in the last years of his government. After Soeharto, Indonesia was led by two presidents who were not elected by the people, B. J. Habibie and Abdurrahman Wahid. When Megawati Soekarnoputri, the chairperson of PDIP, became president in 2001, life became harder and harder, partly because Indonesia did not yet recover from the 1997 Asian financial crisis. In later years, there was a growing disappointment with president Megawati's government, because corruption cases became endemic and the judicial system was weak. Golkar's campaigns in 2004 elections often reminisced those golden years of Soeharto, and constructed the image that General Wiranto was the strong leader Indonesians had longawaited.

In the news text, however, the concept of a "strong leader" was contradicted with General Wiranto's action. First was in making decision. The first sentence labeled him as "the one-time Indonesian strongman" (Extract 8), but further details did not extend this idea. He could not make a simple decision on which transportation to take to the campaign venue: the Mercedes or the becak. The Mercedes was by all means convenient but it created a big gap with his supporters or voters who were mostly ordinary people. The final decision was a compromise as the 
second part of Extract 8 shows: he took the Mercedes first then switched to the becak near the entrance of the venue.

(8) The one-time Indonesian strongman Wiranto could not decide whether to take the Mercedes or the becak, the tiny threewheeled cycle-powered rickshaws that transport the country's poor.

In the end, the former defence minister, former commander of the armed forces and former adjutant to president Soeharto compromised: he started in the limo and switched to ride the becak the final $\mathbf{5 0}$ metres to the hall in Surabaya where almost 2000 people awaited him.

The newspaper sensed that his decision was again based on the need to "woo" his voters that he was a humble leader and possessing solidarity to the poor people. However, his act was represented as insincere because taking the becak was only used as a show to give good impression to the audience. In another part of the text, he was reported to take "a Falcon executive jet" to fly around Indonesia during the campaign.

The second challenge to his idea that he was the strong leader that Indonesia needed was the audience and the material of his campaign. To attract voters to come to the campaign, Golkar provided entertainment, money, promotion T-shirt and food as Extract 9 reported.

(9) A bevy of dangdut dancers warmed up the crowd that included well-heeled members of the Golkar party that had backed Soeharto for decades, and jobless men and boys from the country's second biggest city who had come for the \$A1.70 appearance money, the free Golkar-gold shirts and the lunch box.

The audience might have attended the campaign because of the "dangdut dancers" (dangdut is the local Indonesian dance music which is influenced by Indian music and very popular with the majority) since free entertainment was rare. The other reasons could be the money (equivalent to only $\$ \mathrm{~A} 1.70$ ), Tshirt and a lunch box. Thus, the house-packed audience of Wiranto's rally may look good for boosting his popularity report for television coverage, but they may not be his true supporters. It was a public secret that some people could be the supporters of one party for one day and other parties on other days. The entertainment, the pocket money, the Tshirt and the lunch box were the main reason why the people filled up the stadium.
In some democratic countries, a campaign rally may be understood as a platform for candidates to present their political views, stance on controversial issues, their policy, and solutions to convince the audience to support and vote for them. A campaign is also a forum for voters to get information before making decisions on which candidate to vote. However, in Wiranto's campaign, the news reported that he "failed to deliver" his vision-mission (Extract 10).

(10) General Wiranto had told journalists he would unveil his "mission and vision" during the rally, but he failed to deliver. ... He was no more specific in an interview, ...

(11) Details would come later.

The proposed policy, vision-mission, programs and the likes could be hidden or perhaps non-existent. When in Extract 11, the news wrote that "details would come later", it might be just a euphemism suggesting that they may never come. It was written in a full paragraph by itself as if to project its ironic salience. If details are ready, they will be directly presented to the audience and listed in the news report. In addition, the so-called Golkar's agenda were quoted as the following: "upholding the law, restructuring government institutions, eradicating poverty, lowering unemployment, improving education and building national reconciliation". This motto was shown as very general, abstract and similar to those of many other parties. Thus, it sounded just like another political rhetoric.

Finally, General Wiranto's effort to picture himself as the much-needed strong leader was given a backlash in relation to military suppression in East Timor, Aceh, Papua and other regions during Soeharto's rule. The underlying challenge was the following, "was that the kind of 'strong leader' that he said Indonesia needed?" His answer supposedly denied this assumption, as Extract 12 shows.

(12) General Wiranto says that if he is elected it will be because of his qualities and his background, not because the army is trying to regain the influence it once enjoyed. "You should not worry; the military will [sic] again become dominant in national politics."

He was reported to say that "his qualities and his background" should be the winning factors and not the influence of the army. However, these were the issues the Australian newspaper had been concerned for a long time, especially in relation to East Timor issues. His quoted statement was even confusing. If he meant that the people of Indonesia should not worry, the last clause should have been put in 
negative, such as "the military will not again become dominant in national politics". The actual typing could just be a mistyping, but it could also mean to suggest the scepticism of the newspaper about the military. It was never clear.

In this second text, it is seen that the inclusion of Wiranto's military title did not suggest a more positive representation than that in the first text. Rather, it was used as a reminder of his East-Timorrelated allegations. If he had wanted to impress the people that he was the strong leader they needed, the newspaper challenged that image by representing him as a celebrity at one end, and a repressive military officer at the other end. Neither was what Wiranto had wished.

\section{CONCLUSION}

From the analysis of the two texts, it can be seen that the exclusion and inclusion of the "General" title does not change the negative stereotype that the Australian newspaper has had about Wiranto. As part of a representation-making process, the presence or absence of honorification can be the first indicator of representation, but relating it with the other representational choices in the news text can show the representational tendency of the news writers. Given the background context surrounding the news actors, the news writers and readers, the representations of news actors in news articles may suggest the writers' perception about the news actors. The paper has shown how the presence or absence of a military-rank title has worked subtly in the not-so-favourable representation of an Indonesian news actor in the Australian newspaper.

\section{REFERENCES}

Berkowitz, D. A. (1997). Why a "social meanings of news" perspective? In D. A. Berkowitz (Ed.), Social meanings of news: a text-reader (pp. xixiii). Thousand Oaks, CA: Sage.

D’Angelo, P., \& Kuypers, J. A. (2010). Introduction: Doing news framing analysis. In P. D'Angelo, \& J. A. Kuypers (Eds.), Doing news framing analysis: Empirical and theoretical perspectives (pp. 1-15). New York: Routledge.

Darke, P. A. (2005). The changing face of representation of disability in the media. In J. Swain (Ed.), Disabling barriers - enabling environments (pp. 100-105). London \& Thousand Oaks, CA: Sage.

Dwi-Nugroho, A. H. (2013). Media representation of Indonesia in The Sydney Morning Herald from
2004 to 2009. [Ph.D dissertation]. National University of Singapore, Singapore.

Fairclough, N. (1989, 2001). Language and power. London \& New York: Longman.

Fairclough, N. (1997). Media discourse. London \& New York: E. Arnold.

Fairclough, N. (2003). Analyzing discourse: Textual analysis for social research. London: Routledge.

Greenlees, D., \& Garran R. (2003). Deliverance: The inside story of East Timor's fight for freedom. Crows Nest, NSW: Allen \& Unwin.

Jakobson, R. (1960). Closing statement: Linguistics and poetics. In T. A. Sebeok (Ed.), Style in language (pp. 350-377). Cambridge, MA: MIT Press.

Kingsbury, D. (1997). Culture and politics: Issues in Australian journalism on Indonesia, 1975-1993. Brisbane: Centre for the Study of Australia-Asia Relations.

Koshravinik, M. (2009). The representation of refugees, asylum seekers and immigrants in British newspapers during the Balkan conflict (1999) and the British general election. Discourse \& Society, 20, 477-498.

Lamble, S. (2011). News as it happens. Sydney: Oxford University Press.

Moore, M. (2004a, March 20). Let me entertain you: Wiranto woos the voters. The Sydney Morning Herald, p. 17.

Moore, M. (2004b, May 31). Forgiving Gusmao hugs Wiranto. The Sydney Morning Herald, p. 11.

Moore, M. (2004c, November 13). Fears of murder in the air. The Sydney Morning Herald, p. 1.

O'Shaughnessy, M. \& Stadler, J. (2005). Media and society: an introduction (3rd edition). South Melbourne: Oxford University Press.

Stevens-Gupta, I. (2011). Cultural and gender explanations for the (mis)-representation of female athletes in the media. MA thesis. New York: Empire State College, State University of New York.

van Leeuwen, T. (2008). Discourse and practice: New tools for Critical Discourse Analysis. Oxford \& New York: Oxford University Press.

\section{Reference retrieved online}

http://socio-politica.com/2011/09/04/perinta-presidensoeharto-kepada-jenderal-wiranto-mei-1998/ Perintah presiden soeharto kepada jenderal Wiranto, Mei 1998 [Web log post]. (2011, September 4). Retrieved from http://sociopolitica.com/2011/09/04/perinta-presidensoeharto-kepada-jenderal-wiranto-mei-1998/ 